American Journal of Applied Sciences 6 (3): 534-542, 2009

ISSN 1546-9239

(C) 2009 Science Publications

\title{
Heavy Metals and Anion Levels in Some Samples of Vegetable Grown Within the Vicinity of Challawa Industrial Area, Kano State, Nigeria
}

\author{
${ }^{1}$ J.C. Akan, ${ }^{1}$ F.I. Abdulrahman, ${ }^{1}$ V.O. Ogugbuaja and ${ }^{2}$ J.T. Ayodele \\ ${ }^{1}$ Department of Chemistry, Faculty of Science, University of Maiduguri, \\ P.M.B 1069, Maiduguri, Borno State, Nigeria \\ ${ }^{2}$ Department of Chemistry, Bayero University, Kano state, Nigeria
}

\begin{abstract}
Problem section: Effluents from the surrounding industries such as tannery and textile are used by vegetable farmers for the irrigation of their crops. These effluents may contain some toxic metals which bioaccumulate along the food chain. Moreover the uptake of such toxic metals by crops is governed by their availability and concentration in the soil. Therefore such crops may accumulate heavy metals in excessive amount in their various parts. This may ultimately, adversely affect humans and other species that depend on such crops for food, hence the need to evaluate the pollutant levels in vegetables samples in these areas. Approach: Six vegetable samples of various organs were freshly harvested from ten farms within the vicinity of Challawa industrial areas. The concentration of heavy metals which include, $\mathrm{Cu}, \mathrm{Zn}, \mathrm{Co}, \mathrm{Mn}, \mathrm{Mg}, \mathrm{Fe}, \mathrm{Cr}$, $\mathrm{Cd} \mathrm{As}, \mathrm{Ni}$ and $\mathrm{Pb}$, were determined using Perkin-Elmer analyst 300 Atomic Absorption Spectroscopy (AAS). Levels of some anions (nitrate, nitrite, sulphate and phosphate were determined using Hach direct reading 2000 Spectrophotometer. Results: The results obtained from this analysis revealed that $\mathrm{Cr}$ and $\mathrm{Fe}$ shows the highest concentrations, while As shows the lowest levels in the whole vegetable organs studied. The concentrations of the anions ranged between $40.00-1300.00 \mu \mathrm{g} \mathrm{g}^{-1}$ nitrite, $65-1500 \mu \mathrm{g} \mathrm{g}^{-1}$ nitrate, $122.00-765.00 \mu \mathrm{g} \mathrm{g}^{-1}$ and 12.00-60.00 $\mu \mathrm{g} \mathrm{g}^{-1}$. The leaves contained much higher concentrations of heavy metals and anions than roots and stems. Conclusions: The concentrations of the above parameters were higher than the FAO, WHO/EU and FAO/WHO allowed limit. The high values might be attributed to the used of untreated effluents from textile and tanneries industries by farmers for the irrigation of these vegetables. Thus, the high values of these trace metals and anions in the vegetable samples could put the consumers of these vegetables at health risk. Further works should be carried out in the soil samples were the vegetables are grown.
\end{abstract}

Key words: Heavy metals, anions, vegetables, challawa industrial area, kano state

\section{INTRODUCTION}

The consumption of vegetables and fruits as food offer rapid and least means of providing adequate vitamins supplies, minerals and fibre. In these areas of study, vegetables used as food include those used in making soups or served as integral parts of the main sources of a meal ${ }^{[1]}$. Each plants species has its nutritive requirements differing from others. Thus different plants supported by identical solutions will contain varying concentrations of minor and macro elements. Application of industrial effluent decreases the budding and growth rate of vegetables ${ }^{[1]}$. Leafy vegetables occupy a very important place in the human diet, but unfortunately constitute a group of foods which contributes maximally to nitrate and other anions as well as heavy metals consumption. The excessive application of nitrogen and other inorganic fertilizers and organic manures to these vegetables can accumulate high levels of nitrate and other anions as well as heavy metals. Consequently their consumption by humans and animals can pose serious health hazards. Although some heavy metals such as $\mathrm{Cu}, \mathrm{Zn}, \mathrm{Mn}$ and Fe are essential in plant nutrition, many of them do not play any significant role in the plant physiology. The uptake of these heavy metals by plants especially leafy vegetables is an avenue of their entry into the human food chain with harmful effects on health ${ }^{[1]}$.

Food and vegetable crops production and its attendant security is an important aspect of a nations economic stability. It requires access to fertile land, water and in some cases and all other inputs so as to boast the production particularly in poor and developing countries of the world. In Nigeria, Government has in recent years built additional dams and canals for dry season farming and have increased

Corresponding Author: J.C. Akan, Department of Chemistry, Faculty of Science, University of Maiduguri, P.M.B 1069, Maiduguri, Borno state, Nigeria Tel: +2348036000506 
the provision of fertilizers, herbicides, pesticides and modern farm equipments to boost both dry and rainy seasons farming of food and vegetable crops production $^{[2]}$.

While efforts are being consolidated by the government towards improving and increasing food and vegetable crops production, the problem of industrial effluents into water bodies is undermining these efforts, especially in Kano where tannery and textile effluents are discharged into drain which is used for the irrigation of vegetable crops during the dry season farming. Mineral elements are known to be essential in our diet and may enter the food crops or vegetables from soil through mineralilzation by crops, food processing or environmental contamination ${ }^{[3,4]}$. Many researchers have reported trace metals like $\mathrm{As}, \mathrm{Cr}, \mathrm{Cu}, \mathrm{Fe}, \mathrm{Pb}$ and $\mathrm{Zn}$ as components in tannery effluents ${ }^{[2,5,6]}$.

Kano city in northern Nigeria (Lat: N $1159^{\circ} 981^{\prime}$, Long: E $\left.008^{\circ} 31.491^{\prime}\right)$ is home to $(70 \%)$ of Nigerians tanneries. Most of the tannery industries in Kano are in Challawa Industrial Estate. Consequently, the amount of pollutants and wastes generated by the tanning industries pose significant effect on the vegetable crops grown on the Challawa river bank. Since the polluted effluent is used for irrigation to water the vegetable crops along the river bank, trace metals and anions may enter the food chain through irrigated crops thereby exposing consumers of these vegetable crops to bioaccumulation of trace metals and anions with time. Thus, the need to carry out extensive screening on the vegetables grown in the vicinity of the Challawa river in order to have a comprehensive report on the impact of tannery operations in the area. It was in this regard, that vegetables which are some of the crops grown for commercial purposes were screened in order to assess the level of trace metals and some anions.

\section{MATERIALS AND METHODS}

Sample area and sampling: Vegetable samples such as spinach (Amaranthus caudatus), carrot (Daucus carota), lettuce (Lactuca sativa), cabbage (Brassica oleracea), tomato (Lycopersicon sculenetum)and onion (Allium cepa) irrigated from the Challawa river bank were freshly harvested from ten farms sites and packaged into labelled paper bags and transported to the laboratory awaiting analysis. The vegetable samples were collected for a period of one year, represent the dry and rainy season and divided into root, stem and leaf.

Sample preparation and digestion for heavy metals determination: The vegetables samples were weighed to determine the fresh weight and dried in an oven at $80^{\circ} \mathrm{C}$ for $72 \mathrm{~h}$ to determine their dry weight. The dry samples were crushed in a mortar and the resulting powder digested by weighing $0.5 \mathrm{~g}$ of oven-dried ground and sieve $(<1 \mathrm{~mm})$ into an acid-washed porcelain crucible and placed in a muffle furnace for four hours at $500^{\circ} \mathrm{C}$. The crucibles were removed from the furnace and cooled. $10 \mathrm{~mL}$ of $6 \mathrm{M} \mathrm{HCl}$ was added covered and heated on a steam bath for $15 \mathrm{~min}$. Another $1 \mathrm{~mL}$ of $\mathrm{HNO}_{3}$ was added and evaporated to dryness by continuous heating for one $\mathrm{h}$ to dehydrate silica and completely digest organic compounds. Finally, $5 \mathrm{~mL}$ of $6 \mathrm{M} \mathrm{HCl}$ and $10 \mathrm{ml}$ of water were added and the mixture was heated on a steam bath to complete dissolution. The mixture was cooled and filtered through a Whatman no. 541 filter paper into a $50 \mathrm{ml}$ volumetric flask and made up to mark with distilled water.

Elemental analysis of samples: Determination of $\mathrm{Cu}$, $\mathrm{Zn}, \mathrm{Co}, \mathrm{Mn}, \mathrm{Mg}, \mathrm{Fe}, \mathrm{Cr}, \mathrm{Cd} \mathrm{As}$, $\mathrm{Ni}$ and $\mathrm{Pb}$ were made directly on each final solution using Perkin-Elmer Analyst 300 Atomic Absorption Spectroscopy.

Determination of nitrate, nitrite, sulphate and phosphate in the vegetable samples

Determination of nitrate and nitrite: The concentration of nitrate and nitrite analyzed in each of the vegetable samples were carried out using smart spectro Spectrophotometer (LaMotte 2000). Vegetable samples solutions were prepared by chopping each sample into smaller sizes. A known amount $(1 \mathrm{~g})$ of the chopped sample was transferred into $100 \mathrm{~mL}$ flask and soaked with $50 \mathrm{~mL}$ of distilled water. The flask was capped and shaken for $30 \mathrm{~min}$, then filtered into another $100 \mathrm{ml}$ volumetric flask and the volume made to the mark with distilled water ${ }^{[7]}$ Nitrate was determined spectrophotometrically using standard cadmium reduction method 3649-SC (Lamotte, 2000) while Nitrite was determined using standard diazotization method 3650-SC (Lamotte, 2000).

Determination of phosphate: Each of the vegetables samples was chopped into small pieces. The chopped samples were then air-dried. The air-dried samples were ground and sieved with a siever of mesh $1 \mathrm{~mm}$. A known amount ( $1 \mathrm{~g}$ ) of each of the ground and sieved samples was weighed into acid-washed porcelain crucibles. The crucibles were labeled and $5 \mathrm{~mL}$ of $(20 \%)\left(\mathrm{w} \mathrm{v}^{-1}\right)$ magnesium acetate were added and evaporated to dryness. The crucibles were then transferred into the furnace and the temperature was raised to $500^{\circ} \mathrm{C}$. The samples were ashed at this temperature for $4 \mathrm{~h}$. Removed and cooled in desiccators. 
Ten $\mathrm{mL}$ of $6 \mathrm{M} \mathrm{HCl}$ were then added to each of the crucible and covered, then heated on a steam bath for $15 \mathrm{~min}$. The contents of each crucible were completely transferred into different evaporating basins and $1 \mathrm{ml}$ of concentrated $\mathrm{HNO}_{3}$ was added. The heating was made to continue for $1 \mathrm{~h}$ to dehydrate silica. One $\mathrm{mL}$ of $6 \mathrm{M}$ $\mathrm{HCl}$ was then added, swirled and then followed by the addition of $10 \mathrm{~mL}$-distilled water and again heated on the steam bath to complete dissolution. The contents of the evaporating basins were cooled and then filtered through a Whatman No. 1 filter paper into $50 \mathrm{~mL}$ volumetric flasks and the volumes made up to the marks with distilled water ${ }^{[7]}$. Phosphate was determined using hach direct reading 2000 spectrophotometer.

Determination of sulphate: For sulphate determination, $5 \mathrm{~mL}$ of magnesium nitrate solutions were added to each of the ground and sieved samples in the crucibles. These were then heated to $180^{\circ} \mathrm{C}$ on a hot plate. The heating process was allowed to continue until the colour of the samples changed from brown to yellow $^{[8]}$. The samples were then transferred to the furnace at a temperature of $500^{\circ} \mathrm{C}$ for four hours. Magnesium nitrate was added to prevent loss of sulphur. The contents of each crucible were carefully transferred to different evaporating basins. $10 \mathrm{~mL}$ of concentrated $\mathrm{HCl}$ were added to each of them and covered with watch glasses. They were boiled on a steam bath for $3 \mathrm{~min}$. On cooling, $10 \mathrm{~mL}$ of distilled water were added to each of the basins and the contents of each were filtered into $50 \mathrm{~mL}$ volumetric flasks and the volumes made up to the marks with distilled water ${ }^{[7]}$. Sulphate was determined using smart spectro spectrophotometer (2000).

\section{RESULTS}

The concentrations of heavy metals in different parts of vegetable samples are presented in Fig. 1a and b. The concentrations of heavy metals in different parts of carrot ranged from $3.66-9.23 \mu \mathrm{g} \mathrm{g}^{-1} \mathrm{Cr}, 0.54-2.33 \mu \mathrm{g}$ $\mathrm{g}^{-1} \mathrm{Mn}, .00-4.22 \mu \mathrm{g} \mathrm{g}^{-1} \mathrm{Mg}, 4.00-14.00 \mu \mathrm{g} \mathrm{g}^{-1} \mathrm{Fe}, 0.32-$ $2.00 \mu \mathrm{g} \mathrm{g}^{-1} \mathrm{Cu}, 0.23-01.25 \mu \mathrm{g} \mathrm{g}^{-1} \mathrm{Co}, 0.11-0.34 \mu \mathrm{g} \mathrm{g}^{-1}$ As, 2.00-7.44 $\mu \mathrm{g} \mathrm{g}^{-1} \mathrm{Ni}, 0.32-2.00 \mu \mathrm{g} \mathrm{g}^{-1} \mathrm{~Pb}, 2.00-4.00$ $\mu \mathrm{g} \mathrm{g}^{-1} \mathrm{Zn}, 0.11-1.66 \mu \mathrm{g} \mathrm{g}^{-1} \mathrm{Cd}$ for spinach. 1.00-5.00 $\mu \mathrm{g} \mathrm{g}^{-1} \mathrm{Cr}, 0.61-3.00 \mu \mathrm{g} \mathrm{g}^{-1} \mathrm{Mn}, 0.22-3.12 \mu \mathrm{g} \mathrm{g}{ }^{-1} \mathrm{Mg}$, 2.00-5.00 $\mu \mathrm{g} \mathrm{g}^{-1} \mathrm{Fe}, 0.02-2.00 \mu \mathrm{g} \mathrm{g}^{-1} \mathrm{Cu}, 0.11-0.43 \mu \mathrm{g}$ $\mathrm{g}^{-1} \mathrm{Co}, 0.33-4.00 \mu \mathrm{g} \mathrm{g}^{-1}$ As, $1.00-4.06 \mu \mathrm{g} \mathrm{g}^{-1} \mathrm{Ni}, 0.03-$ $1.00 \mu \mathrm{g} \mathrm{g}^{-1} \mathrm{~Pb}, 2.00-\mathrm{o} 4.00 \mu \mathrm{g} \mathrm{g}^{-1} \mathrm{Zn}, 0.11-2.00 \mu \mathrm{g} \mathrm{g}^{-1}$
Cd for lettuce, 0.21-3.22 $\mu \mathrm{g} \mathrm{g}^{-1} \mathrm{Cr}, 1.54-2.43 \mu \mathrm{g} \mathrm{g}^{-1}$ $\mathrm{Mn}, 0.87-3.21 \mu \mathrm{g} \mathrm{g}^{-1} \mathrm{Mg}, 1.22-4.33 \mu \mathrm{g} \mathrm{g}^{-1} \mathrm{Fe}, 0.12-$ $0.66 \mu \mathrm{g} \mathrm{g}^{-1} \mathrm{Cu}, 0.05-0.54 \mu \mathrm{g} \mathrm{g}^{-1} \mathrm{Co}, 0.05-0.11 \mu \mathrm{g} \mathrm{g}^{-1}$ As, 2.00-5.33 $\mu \mathrm{g} \mathrm{g}^{-1} \mathrm{Ni}, 0.54-2.11 \mu \mathrm{g} \mathrm{g}^{-1} \mathrm{~Pb}, 0.33-3.11$ $\mu \mathrm{g} \mathrm{g}^{-1} \mathrm{Zn}, 0.01-0.44 \mu \mathrm{g} \mathrm{g}^{-1} \mathrm{Cd}$ for cabbage Fig. 1a 2.44-0 7.22 $\mu \mathrm{g} \mathrm{g}^{-1} \mathrm{Cr}, 0.22-1.22 \mu \mathrm{g} \mathrm{g}^{-1} \mathrm{Mn}, 0.12-2.44$ $\mu \mathrm{g} \mathrm{g}^{-1} \mathrm{Mg}, 2.33-8.23 \mu \mathrm{g} \mathrm{g}^{-1} \mathrm{Fe}, 0.22-1.42 \mu \mathrm{g} \mathrm{g}{ }^{-1} \mathrm{Cu}$, 0.11-0.63 $\mu \mathrm{g} \mathrm{g}^{-1} \mathrm{Co}, 0.02-0.11 \mu \mathrm{g} \mathrm{g}^{-1}$ As, $1.02-6.33 \mu \mathrm{g}$ $\mathrm{g}^{-1} \mathrm{Ni}, 0.22-1.23 \mu \mathrm{g} \mathrm{g}^{-1} \mathrm{~Pb}, 1.07-3.22 \mu \mathrm{g} \mathrm{g}^{-1} \mathrm{Zn}, 0.11-$ $1.34 \mu \mathrm{g} \mathrm{g}^{-1} \mathrm{Cd}$ carrot.3.00-12.00 $\mu \mathrm{g} \mathrm{g}^{-1} \mathrm{Cr}, 1.00-6.00$ $\mu \mathrm{g} \mathrm{g}^{-1} \mathrm{Mn}, 0.22-4.00 \mu \mathrm{g} \mathrm{g}^{-1} \mathrm{Mg}, 2.00-10.00 \mu \mathrm{g} \mathrm{g}^{-1} \mathrm{Fe}$, 0.34-2.23 $\mu \mathrm{g} \mathrm{g}^{-1} \mathrm{Cu}, 0.03-1.33 \mu \mathrm{g} \mathrm{g}^{-1} \mathrm{Co}, 0.12-1.87 \mu \mathrm{g}$ $\mathrm{g}^{-1}$ As, $1.55-5.67 \mu \mathrm{g} \mathrm{g}^{-1} \mathrm{Ni}, 2.00-6.66 \mu \mathrm{g} \mathrm{g}^{-1} \mathrm{~Pb}, 2.00-$ $6.00 \mu \mathrm{g} \mathrm{g}^{-1} \mathrm{Zn}, 0.22-1.00 \mu \mathrm{g} \mathrm{g}^{-1} \mathrm{Cd}$ tomato. 3.00-7.00 $\mu \mathrm{g} \mathrm{g}^{-1} \mathrm{Cr}, 1.00-4.00 \mu \mathrm{g} \mathrm{g}^{-1} \mathrm{Mn}, 0.22-3.00 \mu \mathrm{g} \mathrm{g}^{-1} \mathrm{Mg}$, 2.00-7.00 $\mu \mathrm{g} \mathrm{g}^{-1} \mathrm{Fe}, 0.34-1.00 \mu \mathrm{g} \mathrm{g}^{-1} \mathrm{Cu}, 0.03-0.22 \mu \mathrm{g}$ $\mathrm{g}^{-1} \mathrm{Co}, 0.12-1.00 \mu \mathrm{g} \mathrm{g}^{-1}$ As, $1.55-4.33 \mu \mathrm{g} \mathrm{g}^{-1} \mathrm{Ni}, 2.00-$ $5.33 \mu \mathrm{g} \mathrm{g}^{-1} \mathrm{~Pb}, 2.00-4.55 \mu \mathrm{g} \mathrm{g}^{-1} \mathrm{Zn}, 0.22-0.45 \mu \mathrm{g} \mathrm{g}^{-1}$ Cd onion Fig. 1b.

The mean metals concentrations in different parts of vegetable samples during the rainy season are as presented in Fig. 2a and b. The concentrations of heavy metals in the vegetable samples range between 0.21$3.54 \mu \mathrm{g} \mathrm{g}^{-1} \mathrm{Cr}, 0.20-1.34 \mu \mathrm{g} \mathrm{g}^{-1} \mathrm{Mn}, 0.13-2.00 \mu \mathrm{g} \mathrm{g}^{-1}$ $\mathrm{Mg}, 0.56-6.45 \mu \mathrm{g} \mathrm{g}^{-1} \mathrm{Fe}, 0.02-1.33 \mu \mathrm{g} \mathrm{g}^{-1} \mathrm{Cu}, 0.20-$ $0.57 \mu \mathrm{g} \mathrm{g}^{-1} \mathrm{Co}, 0.01-2.00 \mu \mathrm{g} \mathrm{g}^{-1}$ As, $0.50-3.22 \mu \mathrm{g} \mathrm{g}^{-1}$ $\mathrm{Ni}, 0.01-1.01 \mu \mathrm{g} \mathrm{g}^{-1} \mathrm{~Pb}, 0.33-2.00 \mu \mathrm{g} \mathrm{g}^{-1} \mathrm{Zn}, 0.01-1.00$ $\mu \mathrm{g} \mathrm{g}^{-1} \mathrm{Cd}$.

From Fig. 1, 2a and b, the maximum concentration of chromium was in spinach (1.00-9.23 $\left.\mu \mathrm{g} \mathrm{g}^{-1}\right)$ and the minimum in lettuce $\left(0.21-3.33 \mu \mathrm{g} \mathrm{g}^{-1}\right)$. Mn was found in tomato (1.00-6.00 $\mu \mathrm{g} \mathrm{g}^{-1}$ ) while cabbage had the least concentrations $\left(0.22-1.22 \mu \mathrm{g} \mathrm{g}^{-1}\right)$. The highest levels of magnesium were in spinach (1.00-4.22 $\left.\mu \mathrm{g} \mathrm{g}^{-1}\right)$ and the least were observed in cabbage (1.00-2.44 $\mu \mathrm{g}$ $\mathrm{g}^{-1}$ ). Iron had the maximum concentration in spinach (4.00-14.00 $\left.\mu \mathrm{g} \mathrm{g}^{-1}\right)$ and minimum in cabbage (1.22$\left.4.33 \mu \mathrm{g} \mathrm{g}^{-1}\right)$. Copper content was relatively higher in tomato $\left(0.34-2.23 \mu \mathrm{g} \mathrm{g}^{-1}\right)$ while carrot had the least $\left(0.10-1.42 \mu \mathrm{g} \mathrm{g}^{-1}\right)$. Cobalt level was highest in spinach $\left(0.23-1.23 \mu \mathrm{g} \mathrm{g}^{-1}\right)$ and least in onion $\left(0.03-0.11 \mu \mathrm{g} \mathrm{g}^{-1}\right)$. Arsenic showed maximum concentration in lettuce (0.33-4.00 $\left.\mu \mathrm{g} \mathrm{g}^{-1}\right)$ and the minimum in cabbage (0.02$\left.0.11 \mu \mathrm{g} \mathrm{g}^{-1}\right)$. Nickel concentration was highest in spinach (2.00-7.44 $\left.\mu \mathrm{g} \mathrm{g}^{-1}\right)$ and lettuce shows the least (1.00-4.06 $\mu \mathrm{g} \mathrm{g}^{-1}$ ). Lead showed the maximum concentrations in tomato $\left(2.00-6.66 \mu \mathrm{g} \mathrm{g}^{-1}\right)$ and the minimum concentrations in lettuce $\left(0.03-1.00 \mu \mathrm{g} \mathrm{g}^{-1}\right)$. The maximum concentrations of zinc were found in 
tomato (2.00-6.00 $\left.\mu \mathrm{g} \mathrm{g}^{-1}\right)$ and the minimum in cabbage (0.33-3.11 $\left.\mu \mathrm{g} \mathrm{g}^{-1}\right)$. Cadmium showed maximum concentration in lettuce $\left(0.11-2.00 \mu \mathrm{g} \mathrm{g}^{-1}\right)$ and the minimum in cabbage $\left(0.01-0.44 \mu \mathrm{g} \mathrm{g}^{-1}\right)$.

The mean concentrations of nitrate for all the organs of different vegetable samples in the dry and rainy seasons are presented in Fig. 2. The concentrations of nitrate ranged from 244.00-432.00 $\mu \mathrm{g} \mathrm{g}^{-1}$ carrot, 500.00$1300.00 \mu \mathrm{g} \mathrm{g}^{-1}$ spinach, 444.00-765.00 $\mu \mathrm{g} \mathrm{g}^{-1}$ lettuce, 232.00-377.00 $\mu \mathrm{g} \mathrm{g}^{-1}$ cabbage, 40.00-133.00 $\mu \mathrm{g} \mathrm{g}^{-1}$ tomato and 477.00-633.00 $\mu \mathrm{g} \mathrm{g}^{-1}$ onion (dry season), while rainy season ranged from $174.00-237.00 \mu \mathrm{g} \mathrm{g}^{-1}$ carrot, 310.00-543.00 $\mu \mathrm{g} \mathrm{g}^{-1}$ spinach, 273.00-436.00 $\mu \mathrm{g}$ $\mathrm{g}^{-}$lettuce, $123.00-231.00 \mu \mathrm{g} \mathrm{g}^{-1}$ cabbage, 38.00-121.00 $\mu \mathrm{g} \mathrm{g}^{-1}$ tomato and 237.00-394.00 $\mu \mathrm{g} \mathrm{g}^{-1}$ onion. Figure 4 show the concentrations of nitrite in vegetable samples in the dry and rainy seasons, which ranged from
365.00-533.00 $\mu \mathrm{g} \mathrm{g}^{-1}$ carrot, 600.00-1500.00 $\mu \mathrm{g} \mathrm{g}^{-1}$ spinach, 522.00-867 $\mu \mathrm{g} \mathrm{g}^{-1}$ lettuce, $256.00-433.00 \mu \mathrm{g}$ $\mathrm{g}^{-1}$ cabbage, $65.00-211.00 \mu \mathrm{g} \mathrm{g}^{-1}$ tomato and 544.00$700.00 \mu \mathrm{g} \mathrm{g}^{-1}$ onion (dry season) and rainy season ranged from 122.00-212.00 $\mu \mathrm{g} \mathrm{g}^{-1}$ carrot, 253.00$474.00 \mu \mathrm{g} \mathrm{g}^{-1}$ spinach, 222.00-352 $\mu \mathrm{g} \mathrm{g}^{-1}$ lettuce, 121.00-187.00 $\mu \mathrm{g} \mathrm{g}^{-1}$ cabbage, 33.00-63.00 $\mu \mathrm{g} \mathrm{g}^{-1}$ tomato and 232.00-376.00 $\mu \mathrm{g} \mathrm{g}^{-1}$ onion. For sulphate concentration (Fig. 5), carrot ranged from 412.00 to $476.00 \mu \mathrm{g} \mathrm{g}^{-1}, 743.00-1765.00 \mu \mathrm{g} \mathrm{g}^{-1}$ spinach, $588.00-900.00 \mu \mathrm{g} \mathrm{g}^{-1}$ lettuce, 311.00-511.00 $\mu \mathrm{g} \mathrm{g}^{-1}$ cabbage, $122.00-344.00 \mu \mathrm{g} \mathrm{g}^{-1}$ tomato and 765.00-899 $00 \mu \mathrm{g} \mathrm{g}^{-1}$ onion (dry season), while rainy season ranged from 206.00-293.00 $\mu \mathrm{g} \mathrm{g}^{-1}$ carrot, 372.00-812.00 $\mu \mathrm{g} \mathrm{g}^{-1}$ spinach, 253.00-456 $\mu \mathrm{g} \mathrm{g}^{-1}$ lettuce, 156.00-253.00 $\mu \mathrm{g}$ $\mathrm{g}^{-1}$ cabbage, $112.00-156.00 \mu \mathrm{g} \mathrm{g}{ }^{-1}$ tomato and 385.00$453.00 \mu \mathrm{g} \mathrm{g}^{-1}$ onion.

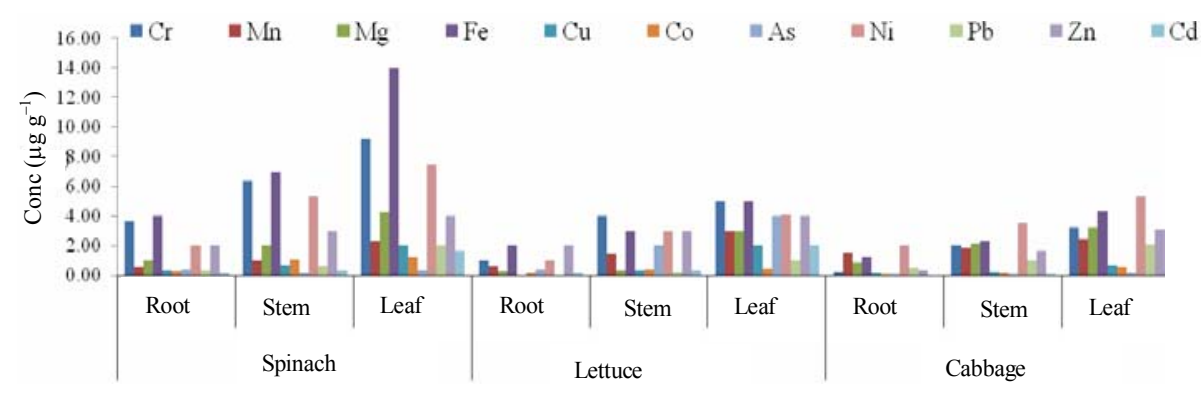

Fig. 1a: Trace element concentrations $\left(\mu \mathrm{g} \mathrm{g}^{-1}\right)$ in different parts of vegetable samples (Spinach, lettuce and cabbage) in dry season from kano industrial area

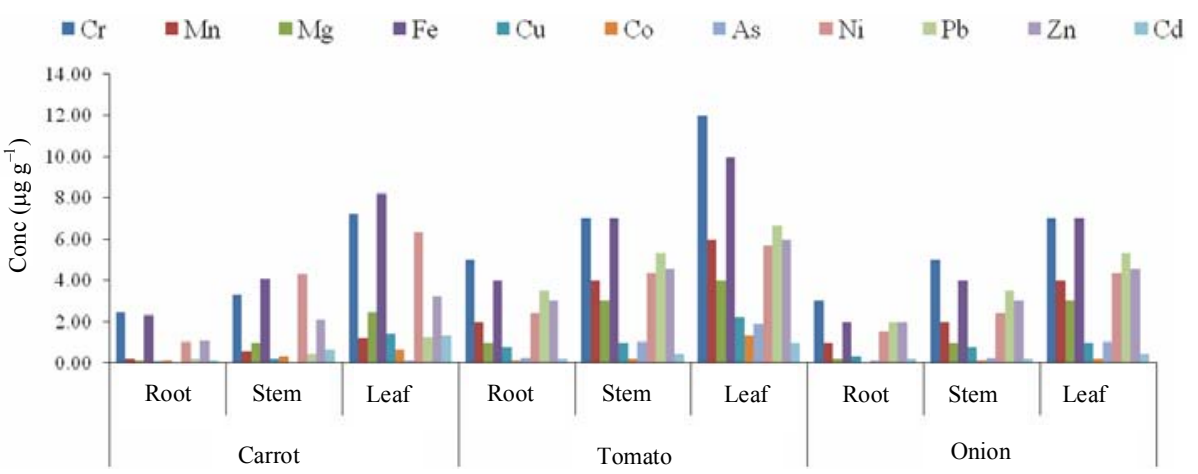

Fig. 1b: Trace element concentrations $\left(\mu \mathrm{g} \mathrm{g}^{-1}\right)$ in different parts of vegetable samples (Carrot, tomato and onion) in dry season from kano industrial area 


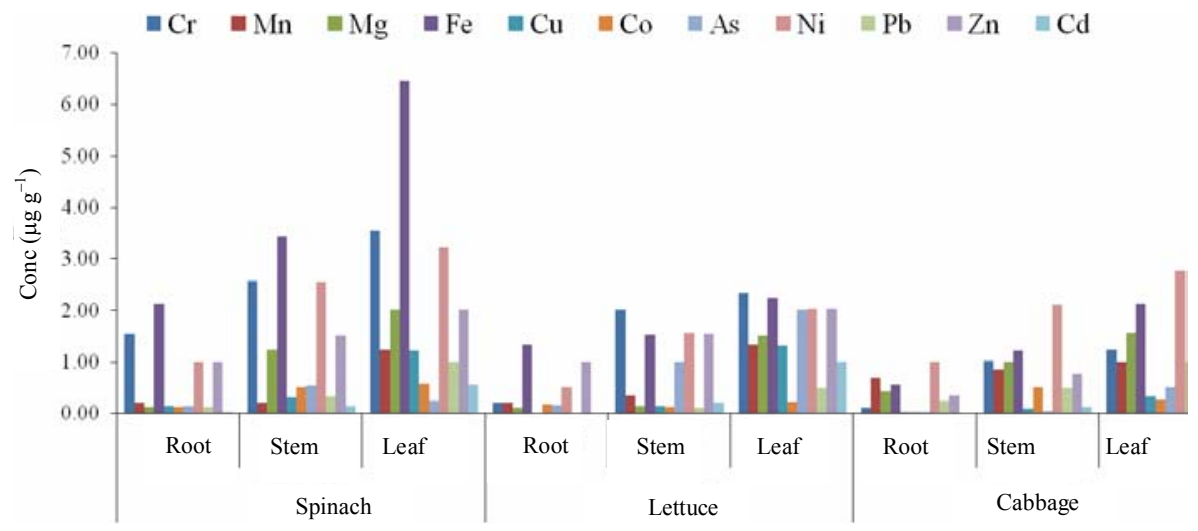

Fig. 2a: Mean metals concentrations $\left(\mu \mathrm{g} \mathrm{g}^{-1}\right)$ in different parts of vegetable samples (Spinach, lettuce and cabbage) in rainy season from kano industrial area

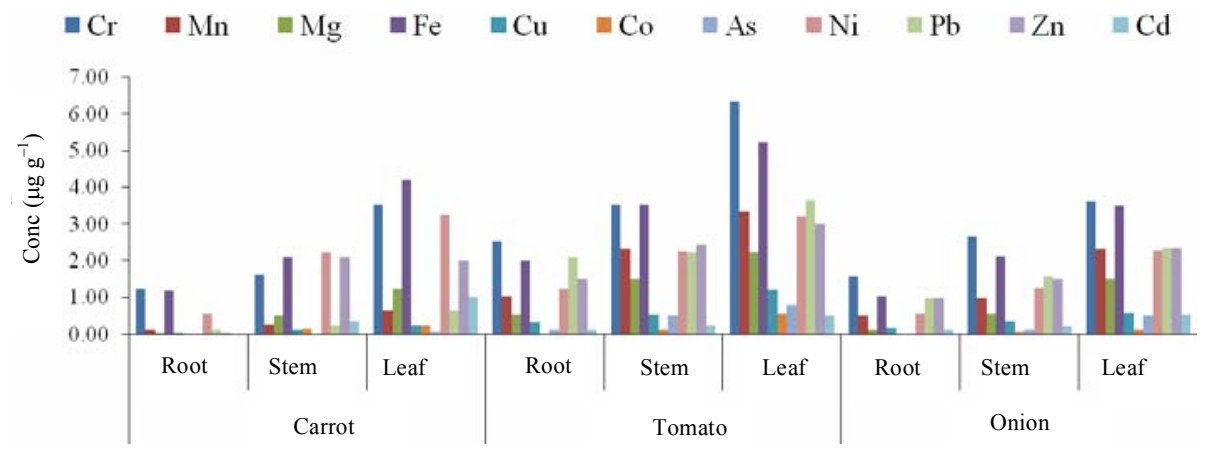

Fig. 2b: Mean metals concentrations $\left(\mu \mathrm{g} \mathrm{g}^{-1}\right)$ in different parts of vegetable samples (Carrot, tomato and onion) in rainy season from kano industrial area

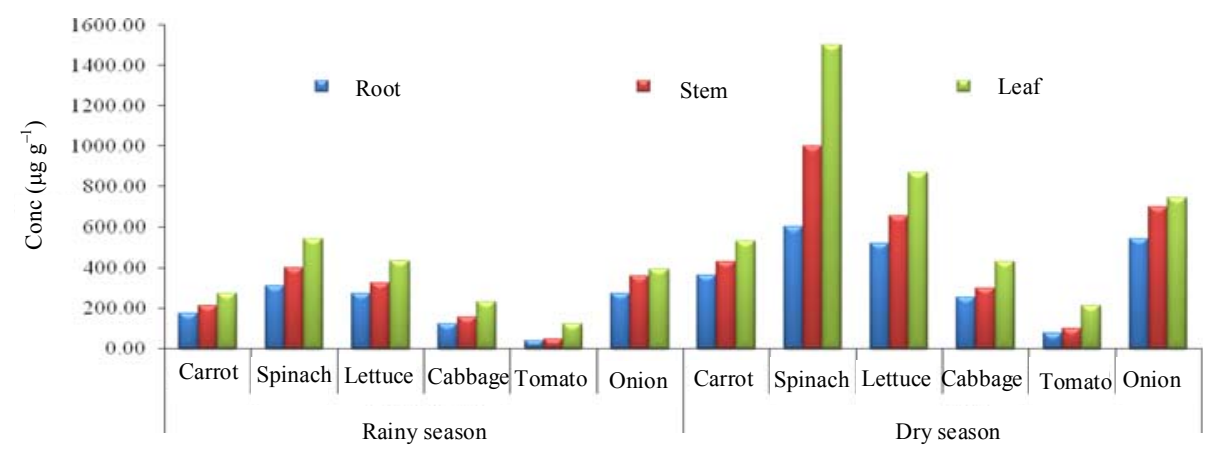

Fig. 3: Seasonal variation of Nitrate concentrations $\left(\mu \mathrm{g} \mathrm{g}{ }^{-1}\right)$ in different parts of vegetable samples from kano industrial area 
Am. J. Applied Sci., 6 (3): 534-542, 2009

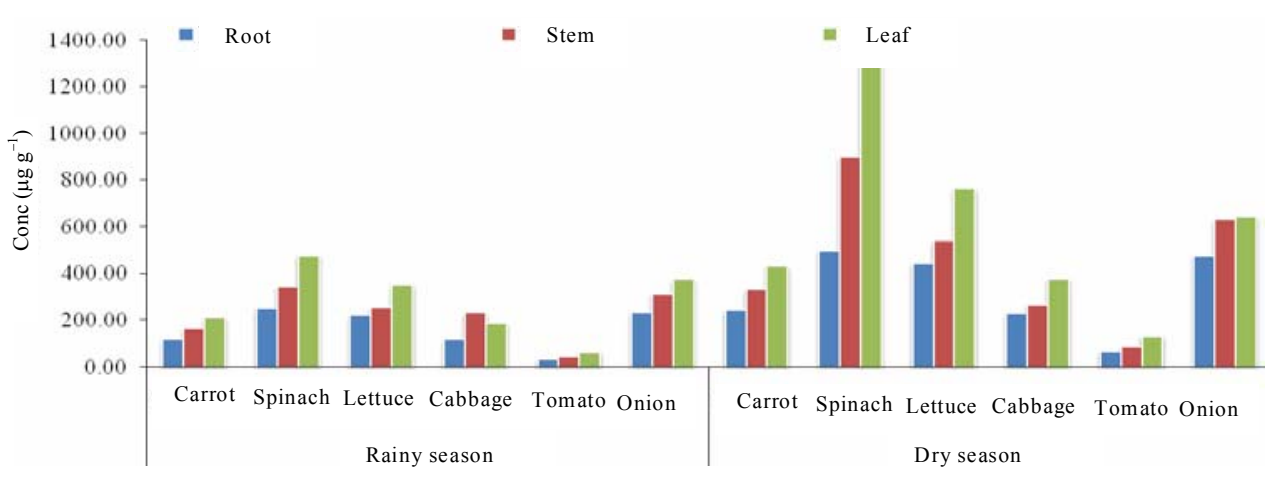

Fig. 4: Seasonal variation of Nitrate concentrations $\left(\mu \mathrm{g} \mathrm{g}^{-1}\right)$ in different parts of vegetable samples from kano industrial area

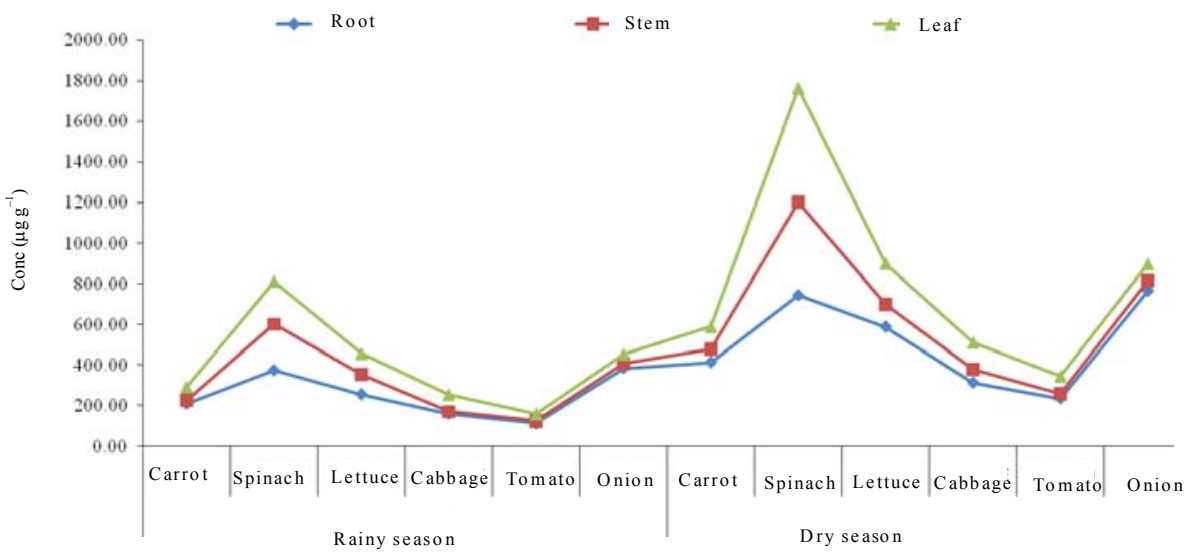

Fig. 5: Seasonal variation of Sulphate concentrations $\left(\mu \mathrm{g} \mathrm{g}^{-1}\right)$ in different parts of vegetable samples from kano industrial area

Phosphate levels ranged from $42.00-80.00 \mu \mathrm{g} \mathrm{g}^{-1}$ carrot, $30.00-60.00 \mu \mathrm{g} \mathrm{g}^{-1}$ spinach, $22.00-80.00 \mu \mathrm{g} \mathrm{g}^{-1}$ lettuce, $30.00-55.00 \mu \mathrm{g} \mathrm{g}^{-1}$ cabbage, $12.00-45.00 \mu \mathrm{g} \mathrm{g}^{-1}$

tomato, $21.00-35.00 \mu \mathrm{g} \mathrm{g}^{-1}$ onion (dry season) and rainy season ranged from $42.00-80.00 \mu \mathrm{g} \mathrm{g}^{-1}$ carrot, 30.00-60.00 $\mu \mathrm{g} \mathrm{g}^{-1}$ spinach, 22.00-80.00 $\mu \mathrm{g} \mathrm{g}^{-1}$ lettuce,
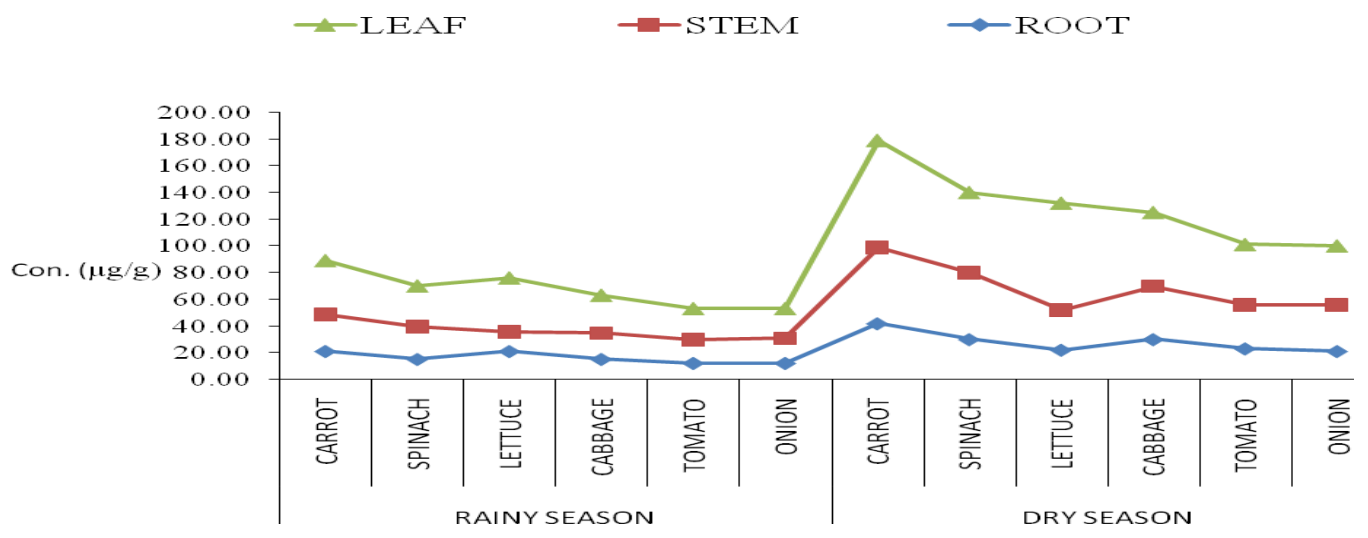

Fig. 6: Seasonal variation of Phosphate concentrations $\left(\mu \mathrm{g} \mathrm{g}^{-1}\right)$ in different parts of vegetable samples from kano industrial area 
30.00-55.00 $\mu \mathrm{g} \mathrm{g}^{-1}$ cabbage, $23.00-45.00 \mu \mathrm{g} \mathrm{g}^{-1}$ tomato and $21.00-44.00 \mu \mathrm{g} \mathrm{g}^{-1}$ onion Fig. 6.

From Fig. 3, the maximum concentration of nitrate was found in spinach (543.00-1500.00 $\left.\mu \mathrm{g} \mathrm{g}^{-1}\right)$ and the minimum in tomato $\left(38.00-211.00 \mu \mathrm{g} \mathrm{g}^{-1}\right)$. Nitrite had the maximum concentration in spinach $(478.00-1300$ $\mu \mathrm{g} \mathrm{g}^{-1}$ ) and minimum in tomato (33.00-344.00 $\mu \mathrm{g} \mathrm{g}^{-1}$ ) Fig. 4. Sulphate content was relatively higher in spinach (812.00-1765.00 $\left.\mu \mathrm{g} \mathrm{g}^{-1}\right)$ while tomato shows the least values (112.00-344.00 $\left.\mu \mathrm{g} \mathrm{g} \mathrm{g}^{-1}\right)$ Fig. 5. Phosphate showed the maximum concentrations in carrot (80.00$80.00 \mu \mathrm{g} \mathrm{g}^{-1}$ ) and the minimum concentrations in tomato (12.00-45.00 $\left.\mu \mathrm{g} \mathrm{g}^{-1}\right)$ Fig. 6 .

\section{DISCUSSION}

In the whole plants studied during the dry and rainy season, leaves contained higher concentrations of heavy metals than roots and stems. Similar study carried out by ${ }^{[9]}$ shows that the heavy metal content of various parts of plant differs. They reported that in vegetables organs the concentrations of heavy metals are in the order of leaf $>$ stem $>$ root $>$ tuber $>$ bulb $>$ fruit $>$ seed. ${ }^{[10]}$ reported high level of heavy metals $(\mathrm{Pb}, \mathrm{Fe}, \mathrm{Cu}$ and $\mathrm{Zn}$ ) in their study of the long term effects of municipal waste disposal on soil properties and productivity of sites used for urban agriculture in Abakaliki, South eastern part of Nigeria. ${ }^{[11]}$ studied plant uptake of heavy metals on a similar site at University of Ife dump site and reported that $\mathrm{Pb}$ uptake by water leaf (Talinum triangulare), okra (Albennucus esculentus) increased in leaves and roots of water leaf and in the fruit of okra relative-those grown in the non-dump sites. Similar work by ${ }^{[12]}$ reported that vegetables accumulate considerable amount of heavy metals especially $\mathrm{Pb}, \mathrm{Cr}$, $\mathrm{Cu}, \mathrm{Zn}$ in roots and leaves.

The concentrations of heavy metals in all the vegetable organs in the dry season were higher than the rainy season. The high concentration of heavy metals in the dry season when compared with the rainy season might be due-the use of untreated effluents from textile and tanneries by farmers for the irrigation of these vegetables during the dry season ${ }^{[6,13]}$. The concentrations of heavy metals in all the vegetable samples in the dry and rainy season were higher than the $\mathrm{FAO} / \mathrm{WHO}$ guideline values of $0.1-0.2 \mu \mathrm{g} \mathrm{g}^{-1} \mathrm{Cr}$, $0.3 \mu \mathrm{g} \mathrm{g}^{-1} \mathrm{Fe}, 0.1 \mu \mathrm{g} \mathrm{g}^{-1} \mathrm{~Pb}, 0.1 \mu \mathrm{g} \mathrm{g}^{-1} \mathrm{Cu}, 0.1 \mu \mathrm{g} \mathrm{g}^{-1}$ $\mathrm{Zn}, 0.1 \mu \mathrm{g} \mathrm{g}^{-1} \mathrm{Ni}, 0.02 \mu \mathrm{g} \mathrm{g}^{-1} \mathrm{Cd}$ and $0.3 \mu \mathrm{g} \mathrm{g}^{-1} \mathrm{Mn}$, with exception of $\mathrm{Co}$ in the rainy season. The presence of these metals in the vegetable samples during the rainy season might be due-some metal residues left behind in the dry season farming. The result of this study agreed with the data reported by ${ }^{[14]}$. Results from present and earlier reports ${ }^{[15]}$ demonstrated that plants grown on wastewater-irrigated soils are contaminated with heavy metals and pose health concern. Absorption and accumulation of heavy metals in plant tissues depend upon many factors. These include temperature, moisture, organic matter, $\mathrm{pH}$ and nutrient availability. The wastewater from tanneries and textile industries used for irrigation showed higher organic matter. The sites irrigated with textile and tanneries effluents also showed similar contamination levels for heavy metals, hence the high content of organic matter. Organic complexing molecules of Low Molecular Weight (LMW) serve as carriers of micronutrients ${ }^{[15]}$. Low Molecular Weight (LMW) has been shown-increase heavy metals uptake ${ }^{[16]}$, while the presence of organic matter has been reported-increase the uptake of zinc, chromium, lead, iron and copper in the wheat plant ${ }^{[16]}$.

The alkalinity range of soil is known-restrict the mobilization of heavy metals, thus reducing their uptake. However, the high nutrient input of irrigated water from these sites could contribute-the high uptake of heavy metals. The field data support this argument in that a higher uptake was recorded at the time when these vegetables were irrigated with textile and tanneries effluent as compared-the time when these effluents were not used. Long-term application of waste effluent is associated with increase in plant uptake and bioavailability of heavy metals ${ }^{[15]}$. In the present study many soil factors such as $\mathrm{pH}$, organic matter, nitrogen bioavailability, soil moisture and temperature have interacted-impact on uptake.

The values of nitrate, nitrite, sulphate and phosphate in the vegetable samples show that the leaves are rich in this anion content than other organs studied. Similar study was carried out by ${ }^{[9]}$ stated that nitrate and nitrite content of various parts of a plant differs in the order of leaf $>$ stem $>$ root $>$ tuber $>$ bulb $>$ fruit $>$ seed. ${ }^{[17]}$ reported that vegetables that are consumed with their roots, stems and leaves have a high nitrate and nitrite accumulation, whereas melons and those vegetables with only fruits as consumable parts have a low nitrate accumulation This observation was also noted by ${ }^{[9]}$ where leaf and stem accumulate the most nitrate, sulphate and nitrite followed by stem and roots. ${ }^{[18]}$ in their study, Nitrate and nitrite accumulation in vegetables, noted that leafy vegetables such as spinachand lettuce contains nitrate, sulphate and nitrite at significant levels. They noted that plants that develop fruits or storage organs, such as potato and tomato, usually have low nitrite and nitrate concentrations. Nitrite content in vegetables is usually very low compared-nitrate ${ }^{[19]}$. Result from this study agreed with 
the above observations. The concentrations of these anions were higher in the dry season when comparedrainy season. The high levels of these anions in the dry season is attributed-the used of untreated effluents from textile and tanneries by farmers for the irrigation of these vegetables, while the low concentrations of these anions during the rainy season are due-the fact that this effluent are not used for the irrigation of these vegetables. The concentrations of these anions in all the vegetable organs study during the dry season were higher than the limits set by WHO. Result of analysis of variance (ANOVA) showed that variation between vegetables and organs were statistically significant $(\mathrm{p}<0.05)$.

\section{CONCLUSION}

The results indicate that all the vegetable samples analyzed in this study had high levels of heavy metals and anions. Heavy metal levels were higher than those recommended by Food and Agricultural Organization (FAO) and the WHO/EU joint limits. The high levels of these heavy metals and anions place the consumers of these and other vegetable crops grown within vicinity of Challawa industrial area at health risk with time unless an urgent step is taken by relevant agenciesaddress this issue.

\section{ACKNOWLEDGEMENT}

I would like-acknowledge Mr. Fine Akawo for his laboratory assistance.

\section{REFERENCES}

1. Ihekeronye, A.I. and P.O. Ngoddy, 1985. Integral Food Science and Technology for the Tropics. 2nd Edn., Macmillian Education Ltd. Oxford and London, pp: 293.

2. Lawal, F.A. and K. Singh, 1981. Analytical studies of wastes water effluents on some tanneries of kano and sokoto states for possible environmental pollution. Bull.Chemical Soc. Nigeria, 6: 68-75. http://www.google.co.uk/search?hl=en\&q=Lawal $\% 2$ C+F.A.+and + K. + Singh\%2C+1981.+Analytical + studies + of + wastes + water+effluents + on + some + ta nneries + of + kano + and + sokoto + states + for + possible +environmental+pollution.+Bull.Chemical+Soc.+ Nigeria $\% 2 \mathrm{C}+6 \% 3 \mathrm{~A}+6875 . \& \mathrm{btnG}=\mathrm{Google}+$ Search \&meta $=$

3. Onianwa, P.C., 2001. Copper and zinc contents of Nigeria foods and estimate of the adult-dietary intakes. Food Chem., 72: 89-95. http://cat.inist.fr/?aModele $=$ afficheN\&cpsidt $=8614$ 36
4. Miller, N.J. 1996. Atomic absorption and atomic emission spectrometry for the determination of consumed in the united states. J. Food Composition Anal.,9: 310-311. Doi: 10.1006/Jfca.1996.9997

5. Lawal, F.A., 1986. Studies on major pollutants in vegetable tannery wastewater. J. Leather Res., 4: 63-74.

http://www.google.co.uk/search?hl=en\&q=vegetab le+tannery+wastewater. $+\mathrm{J} .+$ Leather + Res. $\% 2 \mathrm{C}+4 \%$ $3 \mathrm{~A}+63-74 \& \mathrm{btnG}=$ Google + Search\&meta $=$

6. Yisa, J., 2004. Tannery effluents analysis for challawa industrial estate, Nigeria. In: 16th Annual Conference of International Association of Nigerian Studies and Development, June 15-18, Held at Pioneer Hotel, Wuse, Zone 4, Abuja, Nigeria. pp: 1-28.

7. Radojevic, M. and V.N. Bashkin, 1999. Practical Environmental Analysis. The Royal Society of Chemistry, 2nd Edn., Cambridge, pp: 466.

8. Kenneth Helrich, 1990. Official Method of Analysis of AOAC. 5th Edn., AOAC Inc. Arlington USA

9. Santamaria, P., A. Elia, F. Serio and E. Todaro, 1999. A suevey of nitrate, metals and oxalate content in retail fresh vegetables. J. Sci. Food. Agric.,79:1882-1888.

http://www.google.co.uk/search?hl=en\&q=Santam aria $\% 2 \mathrm{C}+\mathrm{P} . \% 2 \mathrm{C}+\mathrm{A} .+\mathrm{Elia} \% 2 \mathrm{C}+\mathrm{F} .+$ Serio + and + E. + Todaro $\% 2 \mathrm{C}+1999 .+\mathrm{A}+$ suevey + of + nitrate $\% 2 \mathrm{C}+$ me tals + and + oxalate + conten + in + retail + fresh + vegetab les. + J.+Sci.+Food.+Agric. $\% 2 \mathrm{C}+79 \% 3 \mathrm{~A}+1882-$ 1888.\&btnG $=$ Google + Search\&meta $=$

10. Anikwe, M.A.N. and K.C.A. Nwobodo, 2006. Long term effect of municipal waste disposal on soil properties and productivity of sites used for urban agriculture in Abakaliki, Nigeria. Bioresour. Technol.,83:241-251.

http://www.google.co.uk/search?hl=en\&q=Anikwe $\% 2$ C + M.A.N. + and + K.C.A. + Nwobodo $\% 2 C+2006$. + Long+term + effect + of + municipal+waste + disposal + on + soil + properties + and + productivity + of + sites $+u$ sed + for+urban+agriculture + in + Abakaliki $\% 2 \mathrm{C}+\mathrm{Ni}$ geria.+Bioresour.+Technol. $\% 2 \mathrm{C}+83 \% 3 \mathrm{~A}+241$ 251.\&btnG $=$ Google + Search\&meta $=$

11. Amusan, A.A., P.V. Ige and R. Olawala, 1999. Preliminary investigation on the use of municipal waste dump for farming. In: The $25^{\text {th }}$ Annual Conference of Soil Science Society of Nigeria, Nov. 21-25, Benin City, Nigeria. pp: 1-34.

12. Ademoroti, C.M.A., 1996. Standard Method for Water and Effluents Analysis. Foludex Press Ltd, Ibadan pp: 22-23, 44-54, 111-112. 
13. Audu, A.A. and A.O. Lawal, 2005. Variation in metal contents of plants in vegetable garden sites in kano metropolis. J. Applied Sci. Environ., 10:105-109.

http://www.google.co.uk/search?hl=en\&q=Audu\% $2 \mathrm{C}+$ A.A. + and + A.O. + Lawal\% $2 \mathrm{C}+2005 .+$ Variation + in + metal + contents + of + plants + in + vegetable + gard en+sites + in + kano++++metropolis. ++ J.+++Applied +++ Sci.+++Environ. $\% 2 \mathrm{C}+10 \% 3 \mathrm{~A}+105-$

109. \&btnG $=$ Google + Search\&meta $=$

14. Kocak, S., O. Tokusoglu and S. Aycan, 2005. Some heavy metal and trace essential element detection in canned vegetable foodstuffs by differential pulse polarography (DPP). Electronic J. Environ. Agric. Food Chem., 4: 871-878. http://www.google.co.uk/search?hl=en\&q=Kocak $\% 2 \mathrm{C}+\mathrm{S} . \% 2 \mathrm{C}+\mathrm{O}$. + Tokusoglu + and $+\mathrm{S} .+$ Aycan $\% 2 \mathrm{C}$ +2005 . + Some+heavy + metal + and + trace + essential + element + detection + in + canned + vegetable + foodstuf fs+by+differential+pulse+polarography+\%28DPP $\% 29$.+Electronic $+\mathrm{J}$.+Environ.+Agric.+Food + Chem $. \% 2 \mathrm{C}+4 \% 3 \mathrm{~A}+871-$

$878 \&$ btnG $=$ Google + Search\&meta $=$

15. Sharma, R.K., M. Agrawal and F. Marshall, 2007. Heavy metal contamination of soil and vegetables in suburban areas of Varanasi, India. Ecotoxicol. Environ. Safety. J., 66: 258-266. Doi: 10.1016/j.ecoenv.2005.11.007

16. Chen, Y. and T. Aviad, 1990. Effect of Humic Substances on Plant Growth. In: Humic Substances in Soil and Crop Sciences, America Society of Agronomy and Soil Science, Society of America, Madison,WI,pp:161-186.

http://www.google.co.uk/search?hl=en\&q=Chen $\%$ $2 \mathrm{C}+\mathrm{Y} .+$ and $+\mathrm{T} .+$ Aviad $\% 2 \mathrm{C}+1990 .+$ Effect + of $+\mathrm{Hu}$ mic + Substances + on + Plant + Growth. + In\%3A + Hum ic + Substances + in + Soil + and + Crop + Sciences $\% 2 C+$ America + Society + of + Agronomy+and + Soil + Scien ce $\% 2 \mathrm{C}+$ Society + of + America $\% 2 \mathrm{C}+$ Madison $\% 2 \mathrm{C}+$ $\mathrm{WI} \% 2 \mathrm{C}+\mathrm{pp} \% 3 \mathrm{~A}+161-$

186.\&btnG $=$ Google + Search\&meta $=$
17. Zhou, Z.Y., M.J. Wang and J.S. Wang 2000. Nitrate and nitrite contamination in vegetables in china.Food.Rev.Int.,16:61-76.

http://www.google.co.uk/search?hl=en\&q=Zhou\% $2 \mathrm{C}+\mathrm{Z}$. Y.\%2C+M.J.+Wang + and + J.S.+Wang +2000 + Nitrate + and + nitrite + contamination + in + vegetable s+in+china.+Food.+Rev.+Int. $\% 2 \mathrm{C}+16 \% 3 \mathrm{~A}+61$ 76.\&btnG $=$ Google + Search\&meta $=$

18. Maynard, D.N., A.V. Barker., Minotti and N.H. Peck, 1978. Nitrate accumulation in vegetables. J. Adva. Agro., 28: 71-118. http://www.google.co.uk/search?hl=en\&q=Maynar d\%2C++D.N.\%2C++A.V.++Barker.\%2C+++Mino tti+++and+N.H.+Peck\%2C+1978.+Nitrate+accum ulation + in+vegetables.+J.+Adva.+Agro. $\% 2 \mathrm{C}+28 \%$ $3 \mathrm{~A}+71-118 . \& \mathrm{btnG}=$ Google + Search $\&$ meta $=$

19. Aword, O.C., J.R. Hicks, P.O. Minotti and C.Y. Lee, 1980. Effects of plant age and nitrogen fertilization on nitrate accumulation and postharvest nitrite accumulation in fresh spinach. J. Am.Soc.Hort.Sci.,105:18-20.

$\mathrm{http} / / / \mathrm{www} \cdot$ google.co.uk/search?hl=en\&q=Aword $\% 2 \mathrm{C}+++$ O.C. $\% 2 \mathrm{C}+++\mathrm{J} . \mathrm{R} .+++$ Hicks $\% 2 \mathrm{C}++$ P.O. + Minotti+and+C.Y.+Lee\%2C+1980.+Effects + of + pl ant+age + and + nitrogen+fertilization + on + nitrate + ac cumulation + and + postharvest + nitrite+accumulation + in + fresh + spinach.+J.+Am.+Soc. + Hort. + Sci.\%2C $+105 \% 3 \mathrm{~A}+18-20 . \& b \operatorname{tnG}=$ Google + Search\&meta $=$ 